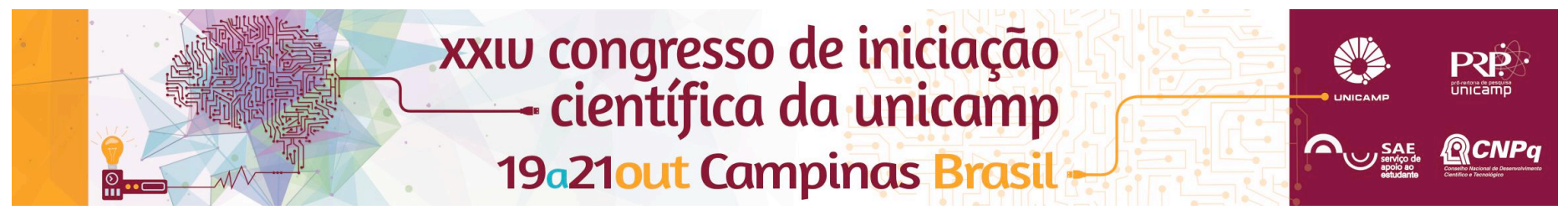

\title{
Avaliação da resistência das cepas de Salmonella e Listeria monocytogenes a diferentes agentes sanificantes
}

\author{
Samuel H. Kumazawa*, Rafael D. Chaves, Anderson S. Sant'Ana.
}

\section{Resumo}

Micro-organismos tais como Salmonella e Listeria monocytogenes são causadores de Doencas Veiculadas por Alimentos (DVAs). Ambas são capazes de formar biofilmes, isto é, uma comunidade de micro-organismos cujas células são aderidas às superfícies, potencialmente levando à contaminação dos alimentos processados. Visando-se inativar os micro-organismos patogênicos e reduzir a contagem dos deterioradores, após o processo de limpeza, são empregados sanificantes, tais como quaternário de amônio, dióxido de cloro, ácido peracético e hipoclorito de sódio. $\mathrm{O}$ objetivo deste estudo foi avaliar a resistência das cepas, bem como do biofilme formado, frente a quatro diferentes agentes sanificantes comumente utilizados na indústria de alimentos (quaternário de amônio, hipoclorito de sódio, ácido peracético e dióxido de cloro), frente à Salmonella (25, 50 e 100 ppm) e Listeria monocytogenes (5, 10 e 20 $\mathrm{ppm})$.

\section{Palavras-chave:}

Salmonella, Listeria monocytogenes, biofilme.

\section{Introdução}

A salmonelose está entre as Doenças Veiculadas por Alimentos (DVAs) com maior relevância em nível mundial $^{4}$. A listeriose é menos comum, porém as consequências advindas da doença são mais graves, e os casos de fatalidade são mais elevados ${ }^{3}$. Falhas nas técnicas de limpeza, sanitização e utilização de CIPs inadequados, podem acarretar na persistência de células aderidas às superfícies de aço inoxidável em áreas de processamento de alimentos, levando à formação de biofilmes $^{5}$. Estes são de extrema importância, pois podem levar à incrustação em trocadores de calor e em linhas de abastecimento de água potável, utilizada para fins industriais ${ }^{1}$, causando deterioração de produtos e ocorrência de surtos de DVAs $s^{1,2}$. O objetivo deste estudo foi avaliar a resistência das cepas, bem como do biofilme formado, a quatro diferentes agentes sanificantes comumente utilizados para fins de limpeza e sanitização (quaternário de amônio, hipoclorito de sódio, acido peracético e dióxido de cloro), utilizando-se de diferentes concentrações de cada um deles $(25,50$ e 100 ppm para Salmonella e 5, 10 e 20 ppm para Listeria).

\section{Resultados e Discussão}

A primeira etapa avaliou se, mesmo após 3 minutos de contato com as concentrações utilizadas de cada sanificante, as cepas apresentavam crescimento quando plaqueadas e incubadas a $37^{\circ} \mathrm{C} / 24 \mathrm{~h}$. A eficiência dos agentes sanificantes foi bastante semelhante para ambos os micro-organismos: o dióxido de cloro apresentou-se mais eficiente, e o quaternário de amônio menos. A diferença observada, contudo, refere-se aos outros dois sanificantes, sendo o hipoclorito de sódio mais eficiente para Salmonella e o ácido peracético para L. monocytogenes.

A segunda etapa avaliou a formação e resistência dos biofilmes de cada cepa. Cupons de aço inoxidável, ilustrando a incidência na indústria, foram incubados em solução contendo o micro-organismo avaliado a $37^{\circ} \mathrm{C} / 24 \mathrm{~h}$, e posteriormente colocado em contato por 3 minutos com o sanificante. As células remancescentes ladaridac an hinfilmal no colııñ foram nlaniıadac incubadas e contadas. A grande maioria das cepas de Salmonella apresentou cerca de duas reduções (em log $\mathrm{UFC} / \mathrm{mL}$ ) se comparadas ao inóculo inicial. Foi possível notar, entretando, que a aderência apresentou-se maior para L. monocytogenes do que para Salmonella, apesar de ambos apresentarem casos de cepas mais e menos resistentes, cujas reduções foram cerca de uma e três unidades, respectivamente. Tal comportamento denota a existência de variabilidade entre as cepas analisadas.

\section{Conclusões}

O quaternário de amônio se mostrou o menos eficiente dentre os sanificantes utilizados, sendo ineficaz para cepas mais resistentes até em sua mais alta concentração testada, ao passo que o dióxido de cloro foi o mais eficiente, erradicando o crescimento dos micro-organismos mesmo utilizando-se baixa concentração. Estes dados ressaltam a importância de se estudar a variabilidade existente entre as linhagens bacterianas, permitindo às indústrias o uso de concentrações mínimas de agentes sanificantes.

\section{Agradecimentos}

Agradeço a todos do laboratório de microbiologia quantitativa de alimentos - FEA/UNICAMP, especialmente ao professor Anderson e ao pósdoutorando Rafael. Agradeço também ao SAE/UNICAMP, pela concessão da bolsa de auxílio à pesquisa.

\footnotetext{
${ }^{1}$ DE BEER, D.; STOODLEY, P. (2006). Microbial Biofilms. In: The Prokaryotes, capítulo 3.10, p.904-937.

${ }^{2}$ KUSUMANINGRUM, H. D.; RIBOLDI, G.; HAZELEGER, W.C.; BEUMER, R.R (2003). Survival of foodborne pathogens on stainless steel surfaces and cross-contamination to foods. International Journal of Food Microbiology, v.85, p.227-236.

${ }^{3}$ MEAD P, SLUTSKER L, DIETZ V, et al. (1999). Food-related illness and death in the United States [review]. Emerging Infectious Diseases, v.5, p.607-25.

${ }^{4}$ TAFIDA, S.Y. et al. (2013). Occurrence of Salmonella in retail beef and related meat products in Zaria, Nigeria. Food Control, v.32, p.119-124.

${ }^{5}$ VAN HOUDT, R.; MICHIELS, C.W. (2009). Biofilm formation and the food industry, a focus on the bacterial outer surface. Journal of Applied Microbiology, v.109, p.1117-1131.
} 